\title{
The materiality or 'thingness' of words and their effects: Some examples from the Book of Proverbs
}

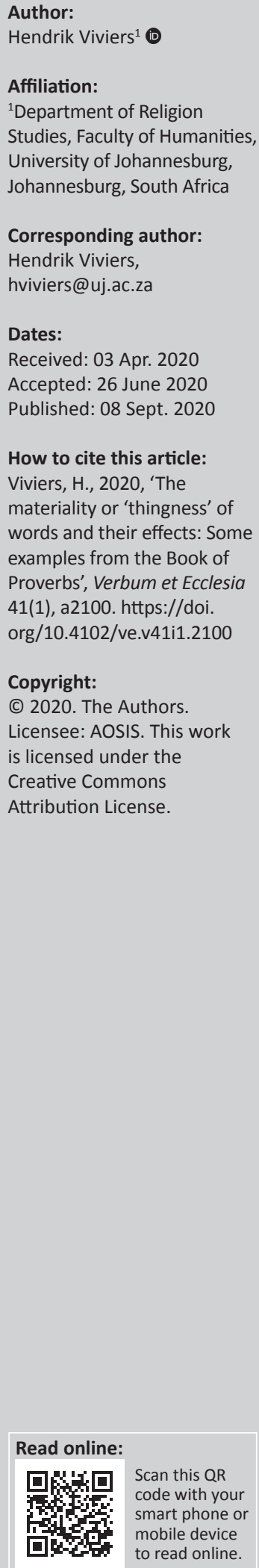

Words are more than vehicles for semantic meaning; they can also be regarded as 'things' with an 'agency' of their own. This happens when they are seen (iconic to legitimise) or heard (performative to inspire). According to S. Brent Plate, a key researcher on materiality (see reference list) 'words are bodies, full of power'. Words, along with many 'things' (fetish, ritual, book, nature, place, etc.) mediate between the material known and the immaterial unknown; they make the invisible visible or experienceable. Birgit Meyer, the pioneer of the so-called material turn in the study of religion, says, words 'effect the transcendental' for the initiated. Not inherently potent but through ascribed or endowed meanings they in turn affect their creators. The so-called material turn in the study of religion has rediscovered that matter or 'things' really 'matters.' Words as powerful 'things' or agents are also attested to in Proverbs. When wisdom words are externalised (e.g. through ornaments, $\operatorname{Pr} 1: 8-9$ ), they legitimise their users; when they are internalised (in the heart or mind, Pr 2), they persuade almost like 'powerful personae' to follow the wise lifestyle; and when they are personified $(\operatorname{Pr} 8)$, they become the 'mediatrix' to the thought-world of wisdom, and its ultimate source, Yahweh.

Intradisciplinary and/or interdisciplinary implications: The material turn in the study of religion (anthropology) emphasises the appreciation of materiality or 'things'. It questions an exclusive mentalistic or inward approach in cognate disciplines, such as Religious Science, Theology and Old Testament and New Testament textual studies. It also stimulates a dialogue with other humaniora such as philosophy, psychology, literary studies, media studies and art history.

Keywords: materiality; 'thing'; words; wisdom; order; visible; invisible; mediate.

\section{Introduction}

Pleasant words are a honeycomb, sweet to the soul and healing to the bones. (Pr 16:24)

Afrikaans church services are often constituted by way of a votum with the words of Psalm 121:1-2: 'Ek slaan my oё op na die berge; waar sal my hulp vandaan kom? My hulp is van die Here wat hemel en aarde gemaak het' (Ou Vertaling, 1953; the New International Version [NIV] translates: 'I lift up my eyes to the hills - where does my help come from? My help comes from the Lord, the Maker of heaven and earth'). These words are so often repeated that their specific (semantic) meaning fades into the background, but this does not make them meaningless. In fact, if spoken by a skilful orator with affection and a fine tonality of voice, the effects of these words become almost tangible. They move, assure and console their listeners, sending a hidden message of trust. If these same words are engraved on a tombstone of a beloved, they can be seen and even touched, with the same effects. They mediate a presence of the deceased through memory; they transcend the user to an unseen, invisible world. Words can only do this if they are 'things' also, apart from their semantic referencing. Therefore, the purpose of this article is to illustrate decidedly the 'thingness' or materialisation of words, and the agency they acquire by becoming 'things' also. It must be admitted that a word's 'thingness' and semantic meaning cannot be dichotomised; they often merge where one evokes the other. ${ }^{1}$ In the following, the wisdom words of Proverbs will be taken as an example to highlight illustratively their functions as they become 'materialised' in diverse ways.

The Book of Proverbs is all about the embracement of wisdom words as they highlight the way of wise living, and this is emphasised throughout. It therefore becomes an apt choice to determine if there is also a sense of wisdom words as 'things', apart from semantically signifying and

1.Watts (2008:3 n. 1) refers to the study of Holdredge on African-American slaves where she shows that it is not only the status of the Bible as a sacred object that matters, but notably its contents that are embraced. 
illustrating the wise lifestyle. Even though the choice of the few examples focused on is from the younger first collection, Chapters 1-9 (titled 'The Proverbs of Solomon, Son of David, King of Israel', from the 4th century BCE) with its longer admonitions, it does not seem that the rest of the collections from diverse eras ${ }^{2}$ have a different (semiotic) ideology about the materiality of words. When studying words as 'things', the focus would usually be on the live performances through which these words can be seen (e.g. the handling of a decorated scroll) or heard (e.g. stories). This is obviously not possible anymore, to see and experience first-hand the 'enactment' of the wisdom of Proverbs. One can only construct or imagine the sociocultural (contextual) world of wisdom as its texts allow a glimpse into that ancient world. In this article, the focus will be mostly on some of the metaphors $^{3}$ that the sages used to 'materialise' wisdom words also. These metaphors could only work if their first hearers or listeners were acquainted with them, if they, for instance, depicted something literal to transmute also into something imaginative. Commenting on the ornament metaphors for words in Proverbs 1:8-9, Fox (2000:85) remarks: '...the ornaments must have been a local custom familiar to the reader; otherwise the imagery and the concepts associated with them would be too fuzzy to be effective'.

In the following the focus will first be on some theoretical insights into what the 'thingness' or materiality of words comprises. Then, some examples from Proverbs on the externalisation of wisdom words as 'things' (Pr 1:8-9; 3:1-4), their internalisation $(\operatorname{Pr} 2)$ and their personification $(\operatorname{Pr} 8)$ will be scrutinised to determine if the ancient sages had an appreciation also for the materialisation of their words.

\section{Words as 'things' and their effects}

Can stones speak? The answer would be both 'Yes' and ' $\mathrm{No}^{\prime}$. No, because they are not sentient, there is no pulsing, biological life in a stone. But even so, we often cherish a stone as if it is 'alive'. In that sense, it can 'speak'; it communicates important meanings to us. These meanings are the meanings that we as subjects have endowed this particular material object with, co-constituting each other as we 'mean' them and they in turn shape us. In this way a stone becomes a medium by connecting us to something invisible or spiritual, a 'world' they represent. Plate (2014a:1) highlights a telling example, namely, the Stone of Anointing in the Church of the Holy Sepulchre in Jerusalem. This flat slab of stone is believed to be the stone on which Joseph of Arimathea prepared Jesus's body for burial, even though the current stone dates back to only 1810. It is perhaps the aura of 'place' along with

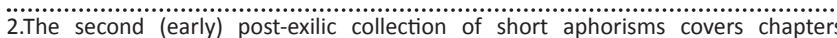
10:1-22:16 ('The Proverbs of Solomon'), the pre-exilic third collection is from chapters 22:17-24:22 ('Proverbs of sages'), the fourth collection covers chapte 24:23-34 ('Further sayings of the wise') and is not easily dateable, the fifth collection is from chapters 25 to 29 ('Hezekiah collection') and dates back to around $700 \mathrm{BCE}$, the sixth collection that covers chapter 30:1-33 ('The words of Agur') is also not easily dateable, as well as the first part of the seventh collection that covers chapter 31:1-9 ('Words of Lemuel'), whilst chapter 31:10-31 ('The noble wife') is post-exilic (see Loader 1987:41-43).

3.To grasp something of the probable 'live poetic performance' of wisdom words and sayings, either when recited or read (e.g. their metre, rhyme, soundplay, etc.), lies beyond the scope of this article. This requires a huge task, almost the same as reconstructing the 'musical performance' of the Psalms. this new stone that has become a 'conduit for sacred energy' (Plate 2014a:1). Pilgrims visit it, touch it, fondle it and kiss it. Through its smoothness and durability it helps them to connect to Jesus. It becomes a medium for remembering. Ordinary stones do the same. Plate's young daughter brought along a ball-sized stone from an unforgettable seaside holiday. She felt the need to bring back something of that environment to be put on the 'altar' of her dresser table (along with other objects), to help her recall the sheer bliss of that holiday (Plate 2014b:30-31). Many people do this, a small pebble to remind and connect us to some special person or experience. A special stone, however, is only significant to its adept and initiated owner, and those outside of this meaning context will find these objects insignificant. Behind this new appreciation of materiality lies the so-called material turn in the study of religion, ${ }^{4}$ where it was found that material artefacts (fetish, ritual, liturgy, body, book, media, nature, place, building, etc.) really 'matter'. These artefacts or 'things' are not inherently potent, but through ascribed or endowed meanings through interpretation, authorisation and ritualisation, they in turn affect in an almost 'magical' way their creators or users, having a 'spell' over them.

It is perhaps redundant to ask if words 'speak'. Of course they do; however, do they speak as objects or 'things' as a stone is able to? But first, is a word an object or 'thing'? Spoken words are substances as sounds, air waves and although airy and evanescent as sound and therefore seemingly immaterial (Weiner 2011:109), they become recognisable as words through their form (phonological, morphological and syntactical) (Keane 2013:5). As they penetrate the listeners' ears (e.g. through loud praying, glossolalia and singing) and are interpreted, they fuse the material (sound) with the nonmaterial (spirit world), having a visceral impact on their receivers (De Witte 2011:152). Words as sounds capture the invisible world almost in a tangible way. Keane (2013:5) argues that words' materialisation is taken a step further as they become scripted, now receiving also orthographic form, including the material with which they are written (ink) and on which they are inscribed (paper, parchment, clay tablet, etc.). Like any other artefact they now can be handled, transported, preserved or destructed. If they are deemed divine words, they in turn mediate the invisible divine world, capturing its presence. Watts (2008:4, following Karel van der Toorn) points out that in ancient Judaism, Torah scrolls functioned in the same way as the divine icons of Babylonian religions, effecting the presence of the transcendental realm. ${ }^{5}$ Moreover, words can also be materialised by ingesting them. The Nafana people in Ghana create a potable tonic by washing

4.The so-called material turn in the study of religion of the past few decades is meant to bring a balance to an exclusive mentalistic or inward/inside approach, where the material expression of religious ideas is down-played or often ignored (Meyer 2014:206).

5.Non-literate cultures do the same, for example, the Sumbanese of eastern Indonesia, who practise haruspicy or entrails divination, where words (thoughts) change into material signs. To contact the spiritual world, a sacrificial animal (pig or change into material signs. To contact the spirtual world, a sacrificial animal (pig or chicken) will be spoken to, to carry these words to the 'other world. In order to see if the spirits answered, the animal would be opened and its entrails then 'read', '.. marks on entrails are visible answers to spoken questions ... signs that arrive from (2013:3). Here is a crossover of semiotic modalities, from speech that becomes answered through signs on entrails. Keane (2013:2) aptly refers to this process as 'spirit writing'. 
off Qur'anic verses from the slates they are written on, and imbibe them for protection (Plate 2011:160). Words are clearly therefore 'things' also.

Although Plate (2011:160) refers to words as 'objects', it is essential to distinguish between 'object' and 'thing'. Brown (2001) describes this difference as follows: an object is something specific whilst a 'thing' implies an:

... [A] udacious ambiguity ... You could imagine things ... as what is excessive in objects, as what exceeds their mere materialization as objects or their mere utilization as objects their force as a sensuous presence or as a metaphysical presence, the magic by which objects become values, fetishes, idols, and totems. (pp. 4-5)

The process for a 'thing' to connect to or mediate an unseen world is aptly described by Keane $(2013: 2,10)$ as transduction or the crossing of different semiotic modalities. ${ }^{6}$ It implies movement from that what cannot be seen to something that can be seen, from non-matter to the material and from the unknowable to the understandable. If words as 'things' accomplish this, then the result is aptly described by Keane as 'spirit writing'. What is in thoughts becomes spoken language, which in turn becomes scripted language '... that can manifest spirit' (Keane 2013:10). When indigenous cultures 'read' the entrails of a sacrificial animal or the book religions 'read' their sacred scriptures, the unseen world becomes materialised in this way. The opposite is also true when 'things' in turn are dematerialised, that is, they transmute into the invisible.

If 'things' are 'more' than objects, it also implies that they have an openness, a multivalency. The meanings they beget differ from individual to individual, or more likely, from one group to another. Words as 'things' do not have any inherent meanings (Keane 2013:11), similar as stones, but they acquire their meanings (and agency) through our efforts to make them meaningful. For 'things' to become meaningful requires much cultural learning, interpretation, ritualisation and authentication by the insider group (Chidester 2018:30, 34, 36). One needs to be culturally initiated to grasp the meanings and effects of the 'things' in use there. In this regard, Keane (2018:65) speaks about semiotic ideology, the underlying assumptions or convictions what 'things' signal or point to and what functions they have, so as to provide their users with an ordered 'world' within which to live. To the devoted Muslim, words as 'things' that can be heard through the azan or public call to prayer, it comes across as soothing and comforting even though the precise meaning of the words might not always be that audible. To the non-Muslim outsider it might come across merely as disturbing noise. ${ }^{7}$

6.Keane (2013:2) describes the process of 'transduction' across semiotic modalities as follows: ' $[c]$ onsider how a turbine works. It transforms the movement of water into power. The water in motion becomes electrical energy. By analogy, semiotic ... power. The water in motion becomes electrical energy. By analogy, semiotic transforming something from one semiotic modality to another'.

7.Plate (2014a:2) illustrates this with the different meanings given to a musical instrument, the drum. The Kebaro (kettle drum) in the Ethiopian Orthodox Church is instrument, the drum. The Kebaro (kettle drum) in the Ethiopian Orthodox Church is
believed to '... signal the presence of the Word of God'. Fundamentalist churches, however, often refer to the use of drums as 'heathen'. Meyer (2012:305), in her
And similarly words that are 'seen', such as calligraphy, where the sight of it deeply moves the informed onlooker, to the non-initiated it is merely some intelligible scribbling on paper. 'Things' mean different things to different people. ${ }^{8}$

Plate (Words 2014) indicates that words as 'things' are usually experienced visually (see), audibly (hear) and sometimes even tangibly (drunk). Words, even though they are written down, usually become invisible as readers proceed to their semantic meanings whilst gleaning over them. The favourite font Helvetica achieves exactly this as it is designed for quick and fluent reading and, whilst non-reflected on by the reader, signals a hidden message (almost a 'spell') that all is fine and good. Beautifully printed Bibles do the same to their readers, signalling a message of consolation apart from their semantic meanings, both when the words are read over and catching the eye. There is therefore also the habit of many users to leather-bind their special Bibles, indicating visually to all onlookers their significance as a sacred collection of divine words. ${ }^{9}$ Keane (2013:8) points out a similar use of the Jewish mezuzah, functioning as an amulet or talisman. This is a small cylindrical container into which a small piece of parchment is inserted, usually inscribed with the Shema (statement of faith), and then stuck to a house's doorpost. The words are now not seen, but they are there and in some way capture the presence of the divine, to offer protection. Through this cultural practice of bequeathing sacred meaning to this particular 'thing' it now acquires 'agency' and functions like '... a certain kind of divine being' (Keane 2013:12). When words are depicted to be deliberately 'seen' as in calligraphic traditions, they trigger '... visceral, emotional responses before and beyond the intellectual capturing of verbal signification' (Plate 2011:159). Keane (2013:8-9) also adds to the example mentioned already of the imbibing of words, where verses of the Qur'an are liquefied and ingested. Although not at the same level as memorising the Qur'an - to internalise it in the head so as to recite it later on - their incorporation into the body becomes more valued than carrying them on the body as a kind of amulet, which could be easily lost.

Moving from 'seeing' to 'hearing', words as 'things' are heard through prayers, scripture reading, sermons, mantras and hymns. Just as we sometimes read over the words without seeing them specifically, we oftentimes also hear words without registering their contents. This usually happens, says Plate (2011:160), when they are so often repeated that they become merely sounds, but to the initiated not empty at all. As familiar sounds, they signify protection, assurance

study on mass-produced pictures of Jesus in Pentecostal churches in Ghana, points out the difference between missionary Protestant semiotic ideology and that of the indigenous Africans. Missionaries valued an immaterial and spiritual Protestantism and dismissed the value of things, notably '... the fetishistic materiality of indigenous cults' (Meyer 2012:305), whilst the locals embraced material things (e.g. pictures of Jesus) to mediate the divine world.

8.Another example concerns the Eucharist: 'Ethnic East Asian Protestant Churches in Los Angeles have used rice for communion - not because they can't find bread but because that's what was used in their members' homeland, in places where bread does not have comparable symbolic powers' (Plate 2014a:3).

9.This inclines to a kind of 'bibliolatry' (Watts 2008:5, referring to Graham), often also the pious practice of not stacking something onto the sacred book, the Bible. 
and consolation. Words then become music ${ }^{10}$ to the ears as they enhance these positive emotions. Even written words can become 'music to the eyes', as Plate (2011:161) indicates, where diacritical and other marks (as part of the calligraphic tradition) in the Qur'an guide the reader to recite it orally touching the hearers' emotions. The same is true also for the Jewish cantor who triggers the emotions in performing ('sing-reading') the Torah. 'In their heard form, the meaning of words is altered, becoming devotional, a force of power, a protection device', says Plate (2011:161). Heard words also confirm identity. With regard to the last-mentioned, Weiner (2011:112) indicates how sounds (and per implication also words) also indicate communal boundaries and power. A ringing church bell or the Muslim prayer conveys and confirms to its followers their in-group, homogeneous status and their hegemony (power) in a certain area over their rival groups - it conveys 'this is us and what we believe in and we're in control here'.

Whether words are seen, heard or incorporated, it is clear that they have 'agency' that affects their users. Watts $(2008: 7,13,14)$ indicates three dimensions or uses of scriptures, namely, semantic, performative and iconic where all the sensual experiences (just named) are present. The semantic dimension is concerned with interpretation and commentary, requiring exegetical expertise, and this is the use of scripture that is probably most frequently practised. In a certain sense, it is a 'form of divination', determining the divine will through incisive interpretation. The function of semantic mastery of scripture is to authorise the most competent interpreter (Watts 2008:7, 13). ${ }^{11}$ The performative use of scripture has to do with private/public reading, memorisation and recitation, chants, dramatisation, artistic displays, calligraphy and so forth and in this way expose their followers to what is theirs, with the aim of inspiring and keeping followers devoted to their tradition (Watts 2008:7,13). The iconic use of scriptures is concerned with their artistic representation, for instance, leather Bibles or illustrated Sanskrit scrolls, and serves the purpose of legitimisation. Bringing classical rhetoric, the art of persuasion by a competent orator, into the picture, Watts (2008:15-17) highlights the well-known notion of 'logos' or the intelligibility of the argument, also 'ethos' or the character or integrity of the speaker and the feelings of the audience, 'pathos'. These three notions are now interestingly and respectively linked to the semantic use (authorising the logical exegete), iconic (legitimising the 'ethical' pastor carrying a leather-bound Bible) and performative (emotionally evocative, inspiring dramatisations). Watts (2008:16) summarises: ' $[i] \mathrm{t}$ may seem odd ... that a book can be described by categories developed for public speakers. Yet ritual emphasis on the logos, pathos, and ethos of scriptures has the effect of giving them personas more like people than like

10. See especially the insightful 2014 book of Töres Theorell, Psychological Health Effects of Musical Experiences: Theories, Studies and Reflections in Music Health Science, which emphassises the amplifying effect of music on emotions.

11.Watts (2008:17) makes the following interesting remark: '... historical study of the Bible has for two centuries challenged scripture's traditional interpretation in Judaism and Christianity. Yet the Bible's religious status within these tradition seems largely unaffected, much to the amazement of many observers'. books ...' Watts continues and elaborates on the personification of scriptures in religious traditions. Sacred books are usually closely linked to their founders, for instance, Moses to the Torah and Mohammed to the Qur'an. Christians regard both Jesus and the Bible as 'the Word of God' according to John 1, which '... equates the logos of God [word, will, revelation] metaphysically with Jesus Christ’ (Watts 2008:16). Some Buddhist traditions venerate and personify their wisdom teachings as a mother goddess, Prajñāpāramitā. She embodies their wisdom, also to shape them, and the specific scriptures containing these wisdom sayings carry her name. In a similar way, Lady Wisdom in Proverbs (wisdom words having become scripture) embodies Israelite wisdom to shape her followers according to the wise lifestyle.

It has hopefully become clear that words are 'things' also, apart from mediums that convey semantic contents. ${ }^{12}$ As 'things' they can be heard, seen or even incorporated to also effect and affect the significance that they have been endowed with. It is now time to appreciate their status as 'things' (how they are materialised) and their 'agency' (what they do) in the Book of Proverbs.

\section{The 'thingness' of words in Proverbs}

What is the invisible world, the ideological or symbolic universe of Proverbs that it wants its readers or audience to enter into, through the mediation of materialised words? It is the idea- or thought-world of wisdom. The wisdom perspective implies a reflective or contemplative observation of reality, an effort to understand its workings and how to resonate with this understanding of reality, in order to be successful in life. Wisdom acknowledges that there is an order in the world, manifesting itself in both the human (moral) and natural domains of reality, without dichotomising these two domains. Behind this order is its ultimate source, namely, Yahweh: Proverbs 1:7 - 'The fear of the Lord is the beginning of knowledge, but fools despise wisdom and discipline'. This is the motto of the book: to be wise is to acknowledge and stand in awe before Yahweh, to believe and to do wise things (Loader 2014:63). Other than a prophet the sage knows God's will through indirect revelation, through the keen observation of reality and inferring what God wants (Loader 2014:39). ${ }^{13}$ The wisdom path ${ }^{14}$ is the life path that a fool does not choose - the fool rejects the wisdom world of meaning. According to Proverbs, the wisdom way of life is

12. In order to further emphasise the materiality of words, and notably metaphors, Plate (2014c) refers to the studies of Mark Johnson and George Lakoff, who emphasised the bodily basis of metaphors. Bodily experiences lead to image schemata, translating into primary metaphors that can map onto other bodily schemata, translating into primary metaphors that can map onto other bodily
domains and finally transmute into abstract thought; for example, 'I feel high domains and finally transmute into abstract thought; for example, 'I feel high today ...', a psychological state that can be traced back to the experience of the
body as a container, where more ('up/high') is positive when the container is filled, whilst less ('down') is negative when the container is emptied. However, it is beyond the scope of this article to trace the 'bodily etymology' of the few metaphors touched on, but merely to grasp the contextual gist of the wisdom author's use of a particular metaphor.

13.Loader (2014:38-39) speaks appreciatively about this kind of 'revelation' as natural religion or theology. Whilst 'ordinary' revelation works according to the scheme 'hear , Yahweh', natural theology's scheme is 'observation/experience , interrelationships > order , creation , Creator , Yahweh'.

14.Fox (2000: 85, 129; see also Loader 2014:66) regards 'path' as a ground metaphor not only for the Book of Proverbs but also for the whole of the Old Testament. He describes such a metaphor as '... an image that organises other perceptions and images and conveys a way of perceiving the world'. 
unproblematic, ${ }^{15}$ what goes around comes around. The predictable outcome that wise or foolish words through their 'agency' accomplish is illustrated throughout Proverbs, for example, Proverbs 12:6: 'The words of the wicked lie in wait for blood, but the speech of the upright rescues them'. The fact that the godly order can be known leads to optimism. The sages are convinced that wisdom can be captured in words, covering an array of topics as rich as life is. In the opening verses of the book ( $\operatorname{Pr} 1: 1-6)$, setting the tone for the book as a whole, wisdom is captured by several lexemes functioning as synonyms for the same concept: wisdom [hokmā], insight [bînā], understanding [těbûnā], prudence ['ormā], shrewdness [mězimmā], knowledge [da'at], teaching [tôrā], admonition or instruction [mûsar], rebuke [tôqahat] and comprehension [tûšiyyā], to name but a few (Van der Ploeg 1952:15). As they become 'materialised' (audibly and visually), capturing wisdom's 'spirit', they become embedded in wisdom's typical genres (e.g. aphorisms, longer admonitions, reflections, numerical sayings, encomiums, etc.) reflective of the wisdom perspective and persuasive of its ethos. How do wisdom words, in their materiality - as 'things' with agency allow or mediate access to this specific idea world?

\section{Wisdom words externalised}

In the introduction to the first admonition or lesson to steer away from sinners, Proverbs 1:8-9, the implied author (narrator) is the educator, addressing the implied reader or pupil (sage to be), by creating a fiction of the typical folk wisdom (tribal wisdom) situation, where the parents are teaching their children (Loader 2014:67-74). He speaks through their 'personae'. Loader (2014:18-19) aptly remarks that the difference between the so-called 'school' and 'folk' wisdom in Israel was not that severe, and this also concerns the court officials who were not aristocratic nobles but also 'small men'. The imperative 'listen' [šĕma'] with which v. 8 starts emphasises the audible receiving of words as 'things'. The parallelism in v. 8 emphasises the teaching role of both father and mother, although the instruction [mûsar] of the father might be stricter than the teaching [tôrā] of the mother. Both terms function as generic terms, without a specific semantic content of these lessons to be taught. They become 'materialised' through the metaphors of v. 9, a garland [liwyat] for the head and necklace ['ănāqîm] for the neck. Waltke (2004:187) aptly remarks, '... they [mûsar and tôrā] are the adornments'. By way of metaphor the author compares one thing in terms of another, to grasp it clearer. Words might be evanescent but being part of a person's adornment, either inscribed ${ }^{16}$ or symbolically ${ }^{17}$ signalling to an invisible reality. The head ornament could also imply a kind of turban with a plate (Scott 1965:38) with something inscribed on it, apart from the usual understanding of a

15.Except in the sixth collection, Proverbs 30:1-33 ('The words of Agur'), where the easily predictable 'Tun-Ergehen-Zusammenhang' is questioned.

16.Waltke (2004:188) points out the recent discovery of two amulets, dating back to the 7th century BCE, inscribed with the priestly blessing (Nm 6:24-26). These amulets most probably functioned as a kind of early phylactery.

17. Meyer and Houtman (2012:14), when referring to the 'agency' of a 'thing', do not prefer the term 'symbol' because the last-mentioned has no life of its own when merely signalling to something else. wreath, and the pendant is hanging from the neck. Waltke (2004:188, following Kayatz) points out a similarity with Egypt where judges and viziers wore a necklace, representing (and 'presenting' - Meyer 2011:62) the Egyptian wisdom goddess Ma'at. She is called the 'necklace', almost captured in this material form and signifying her followers' commitment. Although Fox (2000:84-85) sees less similarity between these ornaments and Ma'at and rather opts for Egyptian tomb banquets or Hellenistic banquets, these material objects (or better 'things') function as 'advertisements' (Waltke 2004:188), reminders (including memory) of the ethos and belief system that they mediate. In the case here at hand, these ornaments worn by both men and women (Loader 2014:75; Toy 1899:14) ${ }^{18}$ mediate the attractive thought-world of wisdom. They become signs of honour, high status and wealth also, indicated by the adjective 'elegant' (hen; the tertium comparationis - Loader 2014:75), and promote an '... attractiveness of manner and bearing' (McKane 1970:268). The embraced and tried and trusted wisdom words of the father and mother can be aptly grasped through their visualised materiality, and apart from conferring honour onto their users, their 'agency' in terms of what was stated above can be described as iconic. When they are 'seen' by those parading with them, they have a legitimising function - they authorise their carriers as true wisdom bearers, in sync with the 'world of wisdom'.

The ornaments motif re-appears in Proverbs 3:1-4 (also $\mathrm{Pr}$ $3: 22 ; 4: 9)$, where the teacher in the role of the father instructs the pupil to internalise ('in your heart' [mind], v. 1) 'my teaching' and 'my commands' [tôrātî, mișwōtay]. The lastmentioned, interestingly for this article on words as 'things', are not semantically qualified, even though it is assumed that they refer to wisdom teaching (Clifford 1999:51; Plöger 1984:33). The instruction here promises a long, qualitative (Murphy 1998:21) and peaceful life. The wisdom concepts kindness and faithfulness [hesed, 'émet] that now beget an ethical connotation (Waltke 2004:241) need to be bound around the neck and written on the tablet of the heart, ${ }^{19}$ both dangling on the heart (v. 3). Scholars note the resemblance with Deuteronomy 6:6-9, of attaching written teaching to the body, mentioned above already with the example of the mezuzah (Clifford 1999:51; Fox 2000:84). ${ }^{20}$ Loader (2014:149) argues that the materialisation of the two words by way of these two 'things' instead of metaphoric should be understood '....as reference to a real necklace inscribed with two specific words from sapiential teaching, namely kindness and faithfulness'. Their prime 'agency' function here is mnemonic (Fox 2000:84; Snijders 1984:36), a 'prosthesis to memory' (Loader 2014:150). Waltke (2004:241) adds to their agency by pointing out their personification ('let them not leave you'). These 'things' are not only a help to remember but also a

18. Whether these ornaments were worn literally and therefore familiar to the readers (Fox 2000:85) or only figuratively imagined, they would have the same effect to portray the materialisation of words.

19.The expression, 'write them on the tablet from your heart', is probably a gloss derived from Proverbs 7:3 (Clifford 1999:50).

20.Toy (1899:58) says, ' $[t]$ he allusion is to the tablets of the decalogue, and to the command ( $\left.\mathrm{Dt} 6^{8.9}\right)$ to write the divine precepts on hands and forehead, doorposts and gates (the later phylacteries, etc.)' 
stimulus to remind of and re-enact the virtues of being kind and trustworthy, namely, the building of character (Fox 2000:145-146). Esteem, recognition and acknowledgment by both God and humans, will follow (v. 4) all through the facilitation of wisdom words having become 'things'.

Might these amulets also function as apotropaic? Apart from the examples indicated that foreground memory, Fox (2000:84) suggests that a '.. trace of the apotropaic use ...' might be found in Proverbs 3:22 where the ornament around the neck will be 'vitality to the throat' to its carrier. In Proverbs 4:9 where (divine) Lady Wisdom crowns the wise pupil with a garland of grace, a crown of splendour, this implies the sharing in divine power to be elevated, and be shielded and protected (Fox 2000:176). And the lastmentioned becomes explicit in Proverbs 6:21-22 where words materialised as 'things' in these amulets act as 'agents' to guide one's life journey ('when you walk, they will guide you'), to protect ('when you sleep, they will watch over you') and communicate to inspire ('when you awake, they will speak to you'). Waltke (2004:242) concurs that 'the radical symbolization' of the wise pupil's identity through the carrying of these amulets in Proverbs 3:3 wards off evil. ${ }^{21}$ Words also function as 'things' including their 'agency' compared to their semantic function. This is clearly present in the ancient Hebrew minds.

\section{Wisdom words internalised}

Moving from the external display of wisdom words as 'things' through (legitimising) ornamentation, the internalisation of wisdom becomes emphatic in the instruction in Proverbs 2. This chapter functions as a foundation for the rest of the book on how to acquire wisdom. The chapter is an enormous long sentence (Clifford 1999:46), commencing with a protasis 'if' ['im] in v. 1-4, followed by an extended apodosis 'then' ['āz], beginning at v. 5 and ending in v. 22. Murphy (1998:14) summarises its overall thrust with 'if ... then ... then ... to save you ... to save you ... in order that you may walk ...' Loader's (2014:103) structuring and summative substantiation of the chapter is as follows: an introductory exordium (A), a lesson-like popositio $\left(\mathrm{B}_{\mathrm{i},} \mathrm{B}_{\mathrm{ii}}\right)$ and a conclusio $(\mathrm{C})$ :

'A If you accept my words (vv. 1-4),

$\mathrm{B}_{\mathrm{i}}$ then you will understand knowledge of God (vv. 5-11)

because God gives wisdom

to guard his faithful

$\mathrm{B}_{\mathrm{ii}} \quad$ in order to save you from all kinds of evil (vv. 12-19)

$\mathrm{C}$ so that you may live a good life and reap its rewards (vv. 20-22)'.

What has probably been composed for the ear originally is now in its written form, catching for the eye (Murphy 1998:14) through its neat and persuasive structure (see, e.g., the chiasms

21. A loud prayer or holding a Bible in front of an attacker to ward off this person is not magic in itself but because of their endowed meanings they become powerful. This can only happen if the assailant shares the same semiotic ideology or meaning carrying assumptions about these 'things'. in vv. $1,4,5,8,10,15,17,19,20,21){ }^{22}$ It is especially in the exordium (protasis) that we find wisdom materialised, and see its agency in action in the propositio (apodosis) and conclusio.

If the teacher's words and commandments need to be accepted and 'treasured up' (verb spn; Loader 2014:101) inside the learner, allowing wisdom to enter the ear and inclining with eagerness the heart (mind) to understand (vv. 1-2), it implies an unquestionable, uncritical and trusting acceptance of wisdom's authority (McKane 1970:282; Plöger 1984:24; Waltke 2004:219-220). This exhortation does not require understanding (Fox 2000:109) but merely its embracement, similarly as an attentive Muslim would respond to the Imam's call for prayer [azan]. The 'thingness' of words to mediate the invisible world is here also illustrated with wisdom words as they become materialised. It is noteworthy that how this description in vv. 1-2 matches the process of transduction explained by Keane above. Wisdom thoughts and ideas, originating from their ultimate source, Yahweh (see v. 6), become materialised as audible words entering the body through the ear and interiorised in the heart/mind through memory for recall and reflection (Clifford 1999:47; see also Waltke 2004:227), to become once again a thought, allowing access or tapping into the ideological world of wisdom. Waltke (2004:220) succinctly captures the 'thingness' of wisdom words being incorporated ${ }^{23}$ : '[ $\left.t\right]$ he metaphor signifies to memorise with religious affection Solomon's "sound bites" in order to have them ready when the occasion demands them ...'

Calling out for insight [labînā] and understanding [latēbûnā] in v. 3 further emphasises wisdom's 'thingness', now as a 'person' to which the son responds (Waltke 2004:221, see $\operatorname{Pr}$ 1:21). Fox (2000:110) reiterates that wisdom, apart from explicit personification (e.g. Lady Wisdom in Pr 1, 4 and 8), is often treated as an animate being, for instance, where she is called to $(\operatorname{Pr} 2: 3)$, where she guards $(\operatorname{Pr} 2: 11)$, where she is embraced (Pr 3:18; 4:8), addressed as sister or friend (Pr 7:4) and having left and right hands (3:16). In light of all this, Murphy (1998:17) regards Proverbs 2:6, where Yahweh gives wisdom, as 'Wisdom (personified)'. And if there is any doubt that wisdom words are 'things' also, v. 4 helps the reader to compare and imagine it in terms of precious silver or hidden treasures. McKane (1970:282) says, ' $[a] l 1$ the words that fall from his teacher's lips are pearls, and they are to be gathered up and carefully kept'. The returning motif of wisdom as ornaments is noticed by Loader (2014:115) as well, emphasising her intrinsic worth.

Verse 5 introducing the elaborated apodosis (' $\bar{a} z$; see also 'áz in 9, the infinitive lěhașşile ke $\bar{a}$ in vv. 12 and 16 and conclusive lěma'an in v. 20) highlights wisdom's 'agency'. If it has been stored inside the learner, then it will mediate the Divine Source of all wisdom thought, part of the immaterial

22.Loader (2014:110) convincingly questions some authors (e.g. Skehan, Murphy and Clifford) that this chapter of 22 verses reflects some kind of acrostic, unlike the Clifford) that this chapter of 22 verses reflects some
Book of Lamentations where it is deliberately used.

23.Waltke (2004:221) interestingly uses the word 'imbibing' for acquiring wisdom Although not literally 'drinking it in' when liquefied as in the few Islamic examples shown above, it has the same mnemonic function when internalised. 
world. The ultimate origin of wisdom is Yahweh or God ('from his mouth'), who gives Wisdom as a 'person' (2:6) that can be known or grasped. Yahweh and Hokmah become almost merged (see below) so that knowing the one is knowing the other, notably in what they effect (Murphy 1998:16). When wisdom becomes incarnate in the wisdom words of the sages, it also has a protective function to guard the life course (way) of the wise (v. 8).

Wisdom also has ethical 'agency' in vv. 9-11 (see Clifford 1999:47; Waltke 2004:227-228), as it shapes and builds character through 'righteousness or fairness' [sedeq], 'justice' [mišpāt] , 'honesty or uprightness' [mēšārîm] and every 'good path' [ma'gal tôb]. The intimate link that wisdom forges between Yahweh, the father's words and the son has the effect that '... the Lord and the son could not be closer' (Waltke 2004:227); it is almost as if God himself enters (becomes present in) the learner's heart through wisdom words (v. 10), to shape him. In other words, the 'spirit of godly wisdom' will be in him, through the internalised words and he will know her intuitively (Waltke 2004:216). And this knowledge [da'at] will also become pleasant [yin'ām] for the soul. Loader (2014:121) aptly describes this as a deep-seated aesthetic experience, touching and moving humans' inner life. Even though the bowels are often associated with feelings and heart with mind (intellect; Toy 1899:33), Fox (2000:109) argues against a dichotomising of the two, where 'heart' can imply emotion also. And wisdom, now as prudence or shrewdness [mězimmā] and practical common sense [těbûnā], will guard the pupil, ending similarly as the previous sub-section (vv. 5-8). Waltke (2004:228) concludes, ' $[a] \mathrm{s}$ the wisdom of God became incarnate in the teacher's words, so God's protection becomes effective through the son's formed character'.

Wisdom's guarding 'agency' of the son continues, this time 'to protect you' (the infinitive lehhașîle ĕka) against wicked men (vv. 12-15) and the bad, strange woman (vv. 16-19). Focusing only on their words here for the purpose of this article, both (bad men and woman) are ardent users of words but of bad words. Fox $(2000: 117,119)$ notes that the wicked man '... speaks tahpukot "crookedness" ...' and the wicked woman's words are characterised by hehĕlîq $\bar{a}$, 'smoothness'. He adds that she is better known for her (almost con artistry [see 7:13-20] with) smooth and sly words (vv. 2:16, 5:3; 6:24; $7: 5,21 ; 22: 14)$, rather than for her looks, that is mentioned only in v. 6:25. Waltke (2004:229) emphasises that their words have '... dynamic spiritual powers ...' similar to wisdom words and words in general being 'bodies with power' (Plate 2011:161). Their words as active 'things' also have effects and affects, but quite the opposite than wisdom words. Their semiotic ideologies clearly differ. The implied author's assumptions about wisdom words as 'things' are divine, inspiring, life enriching and life affirming, as they mediate and make present all these positive things. Foolish and wicked words, however, which the implied author constantly juxtaposes to wise words throughout the Book of Proverbs, embody exactly the opposite values. Wicked men skew life, they disorder it and their life course is 'to walk in dark ways' (v. 13). The evil woman destroys life as her words (and deeds) effect death, and her 'path' leads to sheol (underworld) among the dead (v. 18).

Wisdom's agency continues in the final summary (vv. 20-22) 'so that ...' (lemma'an). Those who internalise the 'spirit' of wisdom will consequentially live the good, ethical lifestyle (v. 20) and will enjoy the plenitude of the land (v. 21). Exactly the opposite will be the fate of the wicked (v. 22). Waltke (2004:234-235) states that 'land' ['eres] should rather be understood with regard to its 'fatness' and not primarily as the (promised) 'land theology' of Deuteronomy (Loader 2014:135). Verses 21-22 form a conspicuous antithetical parallelism (Loader 2014:133) to juxtapose the reward of the upright wise with the fate of the wicked foolish. 'They will be cut off' [yikkārēt û] from the land, which is their physical sustenance as well as being socially ostracised excommunicated through extermination (Waltke 2004:235).

The overall agency of wisdom words, having become a person also, can in light of what Watts has explained above be described as persuasion. Although not performing on a stage to persuade, their performance as 'things' (having become wise values) when internalised in the heart likewise convinces of the good and ethical wise life. They are like interiorised 'personae' with good ethos (see Watts 2008:16) to shape their recipients similarly. They embody this kind of life and want to instil it in their pupils. Along with this they are also authoritative agents; they stem from Yahweh himself and are legitimised by him.

\section{Wisdom words personified}

What has been said above about the personification of words or their materialisation as a person is also true for wisdom words in Proverbs embodying Israel-specific nuances. The personification of wisdom words has been touched on already, but as Fox (2000:332) indicates, it has been inchoate. We, however, find a full-fledged personification in Proverbs 1:20-33, 8 and 9:1-6 where Lady Wisdom is presented. Personification, says Fox (2000:341), is the making of something ambiguous or multifaceted (including the abstract) more concretely graspable and experienceable. This is especially true in the performative contexts where Lady Wisdom is introduced. At the same time, because of its generality of personification, it transmutes again into the invisible. This aptly matches the definition of a 'thing', which has an openness of meaning, but also an unmistakable materiality/'thingness', which can be seen, heard and even touched and again dematerialised to link to the abstract world. Lady Wisdom has in the past been understood in many ways, for instance, a prophet $(\operatorname{Pr} 1: 20-33$, resembling Jeremiah), herald, angel, goddess such as Ma'at or Isis, human women (lover, mother), teacher and so on (Fox 2000:333-341). Even though she might resemble some of the attributes of these figures, as a literary trope she need not fill one of these roles exclusively (Fox 2000:341, 359; Loader 
2014:90). We can see this also in the impressive 'word-picture', the encomium on Lady Wisdom in Proverbs 8 (the focus further) to present her. She can be imagined in many ways, and still retain her own uniqueness, as we shall see how she introduces herself and what she does or effects.

Loader (2014:323) describes the eulogy of Proverbs 8 as a 'substantiated self-recommendation' with the main purpose of convincing her audience of her worth. This is done in a neat, four-division speech, chiastically structured (Loader 2014:321) and therefore contributing to its persuasiveness: A - first admonition, vv. 1-11(where she calls [1-3], what she calls out for [4-6], why she calls out [7-9], value of what she calls for [10-11]); B - wisdom in the present world, vv. 12-21 (her character [12-13], empowerment by her [14-16], her gifts [17-21]); C - wisdom in the primeval world, vv. 22-31 (wisdom as the first of creation [22-26], wisdom and her role during creation [27-31]); and D - final admonition, vv. 32-36. Loader also describes these main sections as 'Call' (A), 'Performance' (B), 'Origin' (C) and 'Love' (D), ${ }^{24}$ which will now be briefly focused on to foreground Wisdom as personified 'thing'.

Wisdom's 'call' (vv. 1-11) starts with her being introduced by the narrator (teacher) in vv. 1-3 (from v. 4 she speaks directly): she is 'Wisdom' [hokmā] and 'Understanding' [tébûnā], ${ }^{25}$ calling from the 'heights' [běrō'š-měrōmîm], probably from a parapet or elevated stand to catch the attention (Loader 2014:326), but she also seemingly moves around outside the city gates (Fox 2000:267) to publicly recommend herself (McKane 1970:343). This is typical of a persuasive orator to convince openly of status and competency ('agency') and so become legitimised also in the eyes of the audience. The overt Lady Wisdom is deliberately pictured as the opposite of the covert Lady Folly, the 'strange wife' ['厃̂šša $z \bar{a} r \bar{a}]$ ' '... who operates under the cover of darkness $(7: 5,9)$...' (Murphy 1998:49). In vv. 4-6, Wisdom is both the subject and object, by speaking herself about herself. The focus of her call is the 'gullible' (Waltke 2004:386, 396), that is, all people and not men only (Loader 2014:327) who find themselves in the public space. Her words are straight or right [něgîlim], upright or integrity [mēšârîm]. It is clear again that her words function here generally as 'things', not specified by a particular semantic reference and they communicate selfrecommendation (Mckane 1970:343). Snijders (1984:63) says, '... geen sprake ... van onderricht, maar van een uitnodiging aan de voeten van de wijsheid te gaan zitten'. This is almost similar to the call of the Imam (above) that should be accepted and not questioned. Her words are ethical (Murphy 1998:50; Waltke 2004:396) and by implication also reflect her ethical character or ethos (see above). This is continued in vv. 7-9, why or on what grounds may she call out. She speaks truth

24.Murphy (1998:54-55) indicates a 'Steigerung' in the chapter: from modest beginnings to a kind of 'social worker' amongst the kingship, then the astounding focus on Wisdom's early origins and then the climax (vv. 30-31), the intimate relationship she has with both Yahweh and humankind.

25.Loader (2014:325) argues that 'Understanding' should be capitalised as a proper noun, because of Wisdom's personification. Along with 'Wisdom' and 'Understanding', her other most often used description is bîna [insight] (Fox 2000:338) ['émet ] and her lips detest wickedness (v. 7), she speaks 'justly' ('in righteousness', běședeq) and not crooked (v. 8), ${ }^{26}$ '... indicating the character of those words' (Loader 2014:329). Loader (2014:329) shows the similarity between these words spoken by Wisdom and Deuteronomy (e.g. 32:4, 5), subtly indicating that she speaks with the authority of God. The value of what wisdom calls for exceeds the worth of money (vv. 10-11, silver, gold, rubies) but it does not exclude material wealth (Loader 2014:331).

Wisdom's status and agency in the present world (historic time - Waltke 2004:400), vv. 12-21, are aptly captured by Loader (2014:333), she '... articulates her character as it can be seen in her performance in the actual world ...' Verses 12-13 open with 'I, Wisdom inhabit cunning ...' ('ormā), ${ }^{27}$ along with her finding 'knowledge of discretion/shrewdness' (mězimmā), and she hates ${ }^{28}$ hubris, the evil way and crooked speech (v. 13). She is what she is able to bestow (Murphy 1998:50). ${ }^{29}$ This is taken further when she continues with vv. 14-16, that counsel ['éșā] and judgement [tûšiyyā] are with her (also power, gěbûrā, 14b,) and notably, 'I am insight ('ănî bînā)', showing that it is 'part of her very essence' (Waltke 2004:402). What Meyer (2014:214) has remarked about the blurring of borders between subject and object where the one becomes the other fits this description of the person Wisdom, bequeathing ${ }^{30}$ these wisdom 'things' to kings, other leaders and influential people to empower them (see also Is 11:2). Fox (2000:274) appreciates the universalism of vv. 12-16, to which all people have access to rule justly, and Loader (2014:338) concurs that also young pupils, non-kings, should strive for this wisdom. Verses 17-21 highlight Wisdom's gifts and are conspicuously framed (inclusio) with the words 'those who love me' ('ôhăbay) (Clifford 1999:95; Waltke 2004:403-404). Her gifts of riches and honour or gravitas (McKane 1970:350) ('ōšer-wěkābôd, forming a hendiadys) and so on, her 'fruit' that she generates that surpasses material riches but as before does not exclude them, and her way of righteousness and justness that she walks (she 'practises what she preaches' - Loader 2014:343) can become part of those actively seeking her love, assimilated into their character (Waltke 2004:404). On the reciprocal love between Wisdom and her seeker, Fox (2000:275) says that love implies a convergence and uniting of minds, they co-constitute each other. Fox (2000:276) continues that behind the mutual love between wisdom and humans may lie the motif of divine-human love. Loader (2014:339-340) adds that when Wisdom opens herself to the seeking (lover) pupil, she

26.Apart from the covert and overt appearances of Wisdom and the unchaste wife, Waltke (2004:392, quoting Newsom) also stresses the different ethos of their speech: "[u]nlike the smooth seductive, but deceptive speech of strange woman, wisdom's is "straight," "right," and "true," not "twisted," or "crooked"'

27.The terms used now have more specific semantic qualities than just the generalised 'right or good words' as before. As mentioned in the Introduction, the 'thingness' of words and their semantic meanings cannot really be separated.

28.Fox (2000: 272) regards v. 13 as a pietistic insertion, to soften Wisdom's image of 'shrewdness' and 'craftiness' in v. 12.

29.Loader (2014:337) comments, ' $[t]$ he very assertion that she bestows something simultaneously asserts that she possesses it'.

30.When Loader (2014:335) uses the word 'give', the giving of the virtues and qualities to the pupil, it subtly also confirms the 'thingness' of these virtues, like giving someone a gift. 
opens 'her mystery' to him. 'Mystery', amongst other things, also implies her close connection with Yahweh, her mediating role towards him.

In vv. $22-31,{ }^{31}$ Wisdom's origin in the primordial world is presented, first her age as the first of creation (vv. 22-26) followed by her role in creation (vv. 27-31). Wisdom was indeed 'created' (v. 22, verb $q n h)^{32}$ by Yahweh and not 'acquired' as some would argue. Loader (2014:345-348) critiques Fox (2000:279-281) for choosing the last-mentioned but ironically defending the first-mentioned. She was also the 'first' $\left[r \bar{e}^{\prime}\right.$ sit $\left.t\right]$ of Yahweh's works, both in age and hierarchy. Both these ideas add to the notion of authority that needs to be respected in wisdom thought. As the panoramic scope of creation continues in the negative, (v. 24 to v. 26) 'when there were no oceans ...', there is an interesting progression from the uninhabitable remote oceans (v. 24) to the less remote mountains (v. 25) and finally to human habitation, the land (v. 26). Verse 27 (to v. 29) changes to a positive, 'I was there ...', and now the movement is opposite, from above to below: from the heavens and horizons (v. 27) to the sky and clouds (v. 28a) to the fountains of the deep (v. 28b) to the seashores (v. 29b) and finally the foundations of the earth (v. 29b) (Waltke 2004:411-412, 414). The climax (Murphy 1998:55; Waltke 2004:422) of this sub-section comes in vv. 30-31, portraying what wisdom was doing at the early beginnings, frolicking or delighting [měśaheqet] and rejoicing [ša'ăšu'îm] before Yahweh. How to understand 'āmôn (v. 30) has led to much debate, 'artisan' or 'nurseling'? Loader (2014:359) follows Fox (2000:285-289) who understands 'àmôn as an infinitive absolute Qal, which favours 'nurseling' and therefore Fox's apt description of Wisdom as an '... intimate of God himself ... a darling little girl'. Loader (2014:358) exposes the flaw of the 'artisan' interpretation that artisans and architects do not skip and jump around like children on a building site, which is true also when God built the cosmos. The last two verses also form a telling chiasm noticed by most commentators (e.g. Clifford 1999:97): 'I was daily taking delight, rejoicing before him at all times, rejoicing in his inhabited world, I take delight in human beings' ${ }^{33}$ Clifford (1999) recaps:

The relationship between Wisdom and her disciples on earth in vv. 32-34 mirrors the relationship between Wisdom and Yahweh in heaven. Wisdom is the most honoured heavenly being and is therefore an apt mediator (emphasis HV) of heavenly gifts to the human race. (p. 97)

Waltke $(2004: 394,423)$ similarly calls her a '... one-of-a-kind heavenly mediatrix ...' and Loader (2014:362) adds an aesthetic dimension when he says '... she imbues the workshop of her

31 . Loader (2014:344) indicates that vv. $22-31$ could be a later addition to this chapter but it was integrated artfully and convincingly.

$32.0 n$ the verb holel in v. 24 , Fox (2000:282-283) says, '[ $t$ ] hough we cannot say for certain that holel could not be said of actual fathers, from the attested usages it appears that God is given a female role, though figuratively and allusively...Since divine productivity is not really sexual, tropes for this activity need not be governed by the constraints of human reproduction'. Van der Ploeg (1952:37) dismisses the by the constraints of human reproduction'. Van der Ploeg (1952:37) dismisses the
idea of hypostasis, that Wisdom exists as an independent being outside of Yahweh as one of his attributes, more or less like the Egyptian Ma'at ['balance'] exists as one of his attributes, more
outside of the supreme god Re.

33.Describing the personality of Wisdom, Fox (2000:357) states 'Wisdom needs humanity'.
Father with joy so that he himself also has part of it'. It is clear that personified Wisdom is impressive and persuasive, and has a life-changing ability or agency, connecting the mundane with the sublime.

In the final admonition (vv. 32-36), Wisdom changes her persona from a child to an adult teacher (vv. 32-33) and lover (vv. 34-36). In v. 32, she speaks like the father teacher, 'Now then sons, listen to me ...' and assures them happiness ('ašrê, macarism) on their life course if they keep to her instruction. Verse 34 starts with another beatitude ('ašrê), of the inexperienced young watching her house closely. The image here is that of a lover approaching the door of the beloved (see Pr 5:8; Job 31:9; Cant 5:2; Loader 2014:366; Murphy 1998:54) instead of pupils around their teacher (Mckane 1970:358; Snijders 1984:68). According to Loader (2014:366), this reading makes more sense in light of the contrast between the strange woman (Chapter 7) and Lady Wisdom (Chapter 8). Whoever finds her finds life (v. 35) and whoever rejects her will find death (v. 36).

On Lady Wisdom in Chapter 8, Loader (2014:367) has the final winged words: '[w]isdom is neither self-revelation of creation (Von Rad) nor "the" revelation of God (Murphy), but the insight in creation as the wonderfully ordered work of God' ${ }^{34}$ As wisdom words are ultimately personified in this special Lady, making her an astounding 'thing', she represents, mediates and presents the wonderful 'world' of wisdom thought. She is logos, ethos and pathos all in one.

\section{Conclusion}

Stones and words have one thing in common: they can both 'speak' as 'things' when meaning is bequeathed to them by their users. Apart from their primary function of verbal signification, words have other 'meanings' also when they become materialised. They can now be seen, heard or sometimes even incorporated to effect or make present as 'agents' the non-material, invisible thought-world - and to affect or touch their users deeply. They only 'mean' to insiders with a shared semiotic ideology, to them they are 'music' to their ears but to outsiders they are 'noise.' The ancient Book of Proverbs is quite aware of wisdom words as 'things' also, apart from their semantic meanings that cannot really be severed from these other meanings. When wisdom words are externalised (e.g. through ornaments), they legitimise; when they are internalised (in the heart or mind), they persuade almost as 'powerful personae' to follow the wise lifestyle; and when they are personified, they become the 'mediatrix' to the (life promising) transcendental world of wisdom thought, and its ultimate source Yahweh. Wisdom words almost have a 'spell' over their adherents. An ancient sage would therefore easily identify with a modern Afrikaans churchgoer being 'moved' by the opening words of Psalm 121.

34.Snijders (1984:67) concurs in the same vein: 'wijsheid is een kosmische kracht, de alomvattende wil van God, die zich manifesteert in de schepping en de onderhouding van de wereld, als een eeuwige en onfeilbare gids van de mensheid'. 
The material turn in the study of religious experience has timely emphasised that we are emotional bodies also and not only intellectual minds. This applies to all 'things' that 'matter' because we have learnt to 'mean' them in diverse and special ways, and they in turn shape us.

\section{Acknowledgements Competing interests}

The author has declared that no competing interests exist.

\section{Author's contributions}

I declare that I am the sole author of this research article.

\section{Ethical consideration}

This article followed all ethical standards for a research without direct contact with human or animal subjects.

\section{Funding information}

This research received no specific grant from any funding agency in the public, commercial or not-for-profit sectors.

\section{Data availability statement}

Data sharing is not applicable to this article as no new data were created or analysed in this study.

\section{Disclaimer}

The views and opinions expressed in this article are those of the author and do not necessarily reflect the official policy or position of any affiliated agency of the author.

\section{References}

Brown, B., 2001, 'Thing theory', Critical Inquiry 28(1), 1-22. https://doi.org/10.1086/ 449030

Chidester, D., 2018, Religion: Material dynamics, University of California Press, Oakland, CA.

Clifford, R.J., 1999, Proverbs: A commentary, The Old Testament Library, Westminster John Knox, Louisville, KY.

De Witte, M., 2011, 'Touch', Material Religion 7(1), 148-155. https://doi.org/10.2752/ $175183411 \times 12968355482466$
Fox, M.V., 2000, Proverbs 1-9: A new translation with introduction and commentary, Anchor Bible 18A, Doubleday, New York, NY.

Keane, W., 2013, 'On spirit writing: Materialities of language and the religious work of transduction', Journal of the Royal Anthropological Institute (N.S.) 19(1), 1-17. https://doi.org/10.1111/1467-9655.12000

Keane, W., 2018, 'On semiotic ideology', Signs \& Society 6(1), 64-87. https://doi.org/ $10.1086 / 695387$

Loader, J.A., 1987, 'Spreuke', in J. Burden \& W. Prinsloo (reds.), Tweegesprek met God: Predikers, digters en wysgere, Die literatuur van die Ou Testament, deel 3, pp. 41-48, Tafelberg-Uitgewers, Kaapstad.

Loader, J.A., 2014, Proverbs 1-9, Historical commentary on the Old Testament, Peeters, Leuven.

McKane, W., 1970, Proverbs: A new approach, Old Testament library, SCM, London.

Meyer, B., 2011, 'Medium', Material Religion 7(1), 58-65. https://doi.org/10.2752/17 $5183411 \times 12968355482015$

Meyer, B., 2012 "“There is a spirit in that image": Mass-produced Jesus pictures and Protestant-Pentecostal animation in Ghana', in B. Meyer \& D. Houtman (eds.) Things: Religion and the question of materiality, pp. 296-319, Fordham University Press, New York, NY.

Meyer, B., 2014, 'An author meets her critics: Around Birgit Meyer's "Mediation and the genesis of presence: Toward a material approach to religion"', Religion and Society: Advances in Research 5(1), 205-254. https://doi.org/10.3167/arrs. 2014.050114

Meyer, B. \& Houtman, D., 2012, 'Introduction: Material religion - How things matter', in B. Meyer \& D. Houtman (eds.), Things: Religion and the question of materiality, pp. 1-23, Fordham University Press, New York, NY.

Murphy, R.E., 1998, Proverbs, Word biblical commentary 22, Thomas Nelson, Nashville, TN.

Plate, S.B., 2011, 'Words', Material Religion 7(1), 156-162. https://doi.org/10.2752/1 75183411X12968355482493

Plate, S.B., 2014a, 'Faith of the senses: Christianity in five objects', Christian Century 1-5, viewed 6 August 2019 from http://www.christiancentury.org/article/ 2014-04/faith-senses.

Plate, S.B., 2014b, A history of religion in 51/2 objects: Bringing the spiritual to its senses, Beacon Press, Boston, MA.

Plate, S.B., 2014c, The materiality of metaphor: on words and things, viewed 7 August 2019 from http://materialreligions.blogspot.com.es/2014/11/the-materiality-ofmetaphor-on-words.html.

Plöger, O., 1984, Sprüche Salomos (Proverbia), Biblischer Kommentar Alten Testament, XVII, Neukirchener-Verlag, Neukirchen-Vluyn.

Scott, R.B.Y., 1965, Proverbs, Ecclesiastes, The Anchor Bible 18, Doubleday, New York, NY.

Snijders, L.A., 1984, Spreuken: Een praktische bijbelverklaring, Tekst en Toelichting, J.H. Kok, Kampen.

Theorell, T., 2014, Psychological health effects of musical experiences: Theories, studies and reflections in music health science, Springer, London.

Toy, C.H., 1899, A critical and exegetical commentary on the book of Proverbs, The International Critical Commentary, T\&T Clark, Edinburgh.

Van der Ploeg, J., 1952, Spreuken, De Boeken van het Oude Testament, VIII, J.J. Romen \& Zonen, Roermond.

Waltke, B.K., 2004, The Book of Proverbs: Chapters 1-15, The New International Commentary of the Old Testament, W.B. Eerdmans, Grand Rapids, MI.

Watts, J.W., 2008, 'The three dimensions of scriptures', Postscripts 2(2-3), 1-23, viewed 18 July 2019 from https://surface.syr.edu/cgi/viewcontent.cgi?article= $1082 \&$ context=rel.

Weiner, I., 2011, 'Sound', Material Religion 7(1), 108-115. https://doi.org/10.2752/17 5183411X12968355482259 